Ya. Obikhod

Ukrainian State University of Railway Transport, Kharkiv, Ukraine

\title{
MOBILE USERS' MULTIPLE DETECTION METHOD ON THE BASIS OF THE PARTICLE SWARM OPTIMIZATION IN THE COGNITIVE RADIO NETWORK
}

In the article, the object is mobile users' multiple detection processes based on the particle swarm optimization in the cognitive radio network. The aim of the research lies in the field of the algorithms of the mobile users' detection of the cognitive radio system. In addition, it lies in the area of development of the generalized algorithm PSO-NN and improvement the method of multiple detection by using the particle swarm method and convolutional neural network and its realization. The tasks are to develop the multiple detection architecture, the generalized algorithm PSO-NN, to realize the multiple detection algorithm and to model PSO-NN as the algorithm of the multiple detection effectiveness for 50 mobile devices. The methods used are mathematical models based on the principles of the organization and operations of biological neural networks, mathematical learn models, and NP-hard algorithm theory methods. The following results were received. The multiple detection architecture was developed, which differs from the known ones since each location is divided into the subzones. In the different subzones, a mobile user can receive different measuring results in the same channel. Such a division can be used for more flexible data using. Developed generalized algorithm PSO-NN differs from the known ones as it is configured more correctly for the real conditions that inherent in the architecture of the cognitive systems. This algorithm uses particle swarm optimization controlled by the convolutional neural network. Therefore, strict access to spectrum analysis based on mobile users' energy component is provided. Due to the use of the micro particle architecture and convolutional neural networks, detection effectiveness function and global particle location are detected in a more accurate way. Further implementation of the multiple detection algorithm differs from the known ones since after uniting the detected channel users' matrices, only one user is assigned to a specific channel. Such an implementation assumes more realistic search area and speed of the users' detection with found channels. Modeling PSO-NN as the multiple detection effectiveness algorithm for 50 mobile users has several convolutional layers that were generalised with each other. Such architecture can be a confirmation of the fact that the neural network chosen in a practical way completely satisfies the tasks. The modeling result showed that at 20 locations the detection effectiveness with using the algorithm PSO-NN increased by $10 \%$ in 20 locations, by $20 \%$ in 25 locations, by $20 \%$ in 30 locations, by $20 \%$ in 35 locations, while the results did not change in 40 locations.

Keywords : cognitive radio; particle swarm algorithm; convolutional neural network; radio frequency resource; NP-hard class problem.

\section{Introduction}

A problem statement. In recent years, the wireless traffic has increased significantly. The results also stated about shortage of radio-frequency resource. According to the current international legislation on the fixed access to the radio-frequency spectrum, only licensed users can use it. At the same time, when the radio-frequency spectrum is not used, non-licensed users cannot use the radio-frequency recourse. Such a spectrum distribution policy leads to a low density of the use of radio-frequency resources. To address this problem, the technology of cognitive radio appeared [1]. When the radio-frequency channel is free, cognitive radio allows non-licensed users to use the radiofrequency spectrum. Thus, non-licensed users always analyze the needed frequencies before they use radiofrequency resources.

As the mobile devices appeared, the new technologies emerged. One of them is analysis of big quantity of mobile devices and computers (MCSC Mobile Crowd Sensing and Computing) [2]. The formal definition is described in the following way. The new technology of spectrum analysis allows the usual users to enter the data that is obtained or created by mobile devices in the datacenters with the help of cloud technologies, about the state of its employment.

After the introduction of the MCSC technology, mobile devices can be equipped by tracking sensor that analyzes and measures the radio-frequency spectrum. At the same time, the US Federal Communications Commission decided the secondary television spectrum users under FC (FC - fusion center) management could use the geolocation database. FC determines the mobile device and obtains the analysis data. For stimulating the users for using the MCSC technology, the US Federal Communications Commission provides some encouragements. Such functions and technologies are crowdsourcing. In the research, it is provided for using the crowdsourcing technology for the spectrum analysis with using mobile devices, intended for the user. It is assumed there is the datacenter for data accumulating (FC). The factors described above and have influence on the function of spectrum analysis take into account. In the article, it is proved that the task of multiple detection is the task of NP-hard class. Therefore, it is developed the method based on using particle swarm (PSO) for decision of these tasks. The simulation results show algorithm realizing proposed method, supplies higher productivity in comparison with the known methods.

Analysis of literature. In the cognitive radio systems, the licensed users' activity is detected by clearness or busyness of spectrum [3]. There are factors such as shadow or multipath fading that can lead to the distorted activity of the users' mobile devices. To resolve such problems, the spectrum analysis for the correctness improvement of spectrum analysis is developed [4]. In the wideband wireless system, the users exchange compression results (CS - compressive 
sensing). In [6] the authors assume the two-level protection scheme against interference in the cooperated spectrum analysis. In [7] it is considered the mutual spectrum analysis based on multiple detection with the aim of increasing the protection ratio level. In [8] it is considered the simultaneous spectrum analysis and data communication, in the result of that is was proposed the new model of the detection for the cooperative spectrum analysis. It is envisaged the several recognition strategies for planning the quantity of users based on the network parameters [9]. In [10] it is proposed the theoretic-game mechanism of the power distribution based on the results of measuring the channel of users in the cognitive radio network. To improve the analysis quality, the authors consider the multichannel recognition problem in the multichannel system [11-13]. These systems use the simplified objective function and absent $\mathrm{BC}$ ( $\mathrm{BC}$ - budget constraint). Using the $\mathrm{BC}$ it is possible to choose only one set of the mobile users. In [14] it is considered the $\mathrm{BC}$ at the decision detection and channel division problems. All of these researches don't consider the energy component of mobile users.

In the above-mentioned literature, the centralized algorithms are used. Some widespread spectrum analysis methods exist. In [5], the distributed spectrum analysis method is considered in order to use the spectrum spatial capabilities. To detect the spectrum analysis characteristics, the methods of the stochastic geometry are used. In [10] on the users' channels analysis showings the management mechanism of the power with the using of the game theory is considered.

The aim. The aim of the research lies in the field of the algorithms of the mobile users' detection of the cognitive radio system, in the development of the generalized algorithm PSO-NN, and improvement of the method of multiple detection by using the particle swarm method, and convolutional neural network. Therefore, the tasks are:

- the development of the multiple detection architecture;

- the development of the generalized algorithm PSO-NN;

- the further realization of the multiple detection algorithm;

- modelling PSO-NN, as the algorithm of the multiple detection effectiveness for the 50 mobile devices.

\section{The main part}

$M$ will be the number of places, where the spectrum analysis will take place, $N$ - the number of channels that can be detected in the $j$ point. In the $j$ point, the shadow and multipath fading are represented in addition to other distortions that can influence the results of mobile users' detection in different places of this location. Mobile users can get different results of measuring in the same place. Therefore, it turns out that the mobile users location can be divided into several subzones.

Spatial location can be fixed with the results of mobile users' detection in different locations. In the $H$ zone of the $j$ location, $\mathrm{z}_{\mathrm{h} j}^{\mathrm{i}}=1$ means there is at least one channel of the data communication. At the value $z_{h j}^{i}=0$, it is clear that no data channel was found. In the $j$ location, let $y_{\mathrm{j}}^{\mathrm{i}}$ be the number of subzones where the channel was detected at least one mobile user. We can assume that $y_{\mathrm{j}}^{\mathrm{i}}=\sum_{h=1}^{m(j)} z_{h j}^{i}$, where $m(j)$ - the number of subzones in the $j$ location. It can be assumed, than higher the value of $y_{\mathrm{j}}^{\mathrm{i}}$, the more effective spectrum analysis will be. In $y_{\mathrm{j}}^{\mathrm{i}}=m(j)$, maximum spectrum analysis result will be reached. On this basis, it turns out that spectrum analysis effectiveness will increase when $y_{\mathrm{j}}^{\mathrm{i}}$ represents small values and vice versa. Let $f(i, j)=\sqrt{y_{j}^{i} / m(j)}$ - the effectiveness of $i$ channel of the $j$ location analysis. As a result, the spectrum effectiveness function for the multiple detection can be described in the following way [1]:

$$
\sum_{j=1}^{M} \sum_{i=1}^{N(j)} \omega_{j}^{i} f(i, j)
$$

where $\omega_{\mathrm{j}}^{\mathrm{i}} \quad-\quad$ non-negative weighting value $\sum_{j=1}^{M} \sum_{i=1}^{N(j)} \omega_{j}^{i}=1$, in which $\omega_{\mathrm{j}}^{\mathrm{i}}$ can discern different channel analysis levels in every location.

According to (1), the spectrum analysis effectiveness function is increased when $y_{\mathrm{j}}^{\mathrm{i}}$ is in the range from zero to $m(j)$ and is decreased if $y_{\mathrm{j}}^{\mathrm{i}}$ is increased. To receive realistic spectrum analysis, the spectrum analysis effectiveness function must be maximum, taking into account all local constraints of the $i$ channel, $j$ location and threshold less than $H$. The local constraints can be described [2]:

$$
f(i, j) \geq H, \mathrm{i} \in[1, N(j)], \mathrm{j} \in[1, M] .
$$

There are also factors that must be taken into account. For mobile users, the residual signal energy has to be considered. Only when the residual signal energy of mobile user is higher than the set threshold, a user can carry out the spectrum analysis. Let $T_{h}$ - normalized threshold of the residual energy, $K$ - all mobile users and $e_{k}$ - the residual energy of mobile user. Then, energy constraint can be expressed as [3]:

$$
e_{k} \geq T h, \mathrm{k} \in K \text {. }
$$

Let $M$ be the number of locations that must be analyzed. Only mobile users that are located in the $j$ location can carry out the spectrum analysis. It is assumed mobile user can analyze only one channel. In the $j$ location, $K(j)$ - the set of mobile users, $n(j)-$ the number of mobile users and $N(j)$ - the number of channels that can be analyzed. For mobile users $\mathrm{k} \in K(\mathrm{j}), \mathrm{x}_{k i}=1$ means $i$ channel was detected by the $k$ user. Taking into account that mobile user can analyze 
only one channel it can be expressed all other restrictions as [4]:

$$
\sum_{k \in K(j)} \sum_{i=1}^{N(j)} x_{k i} \leq n(j) .
$$

The incentive scheme assumes the FC will pay the bills of mobile users that try to analyze the frequency spectrum. Such cost of multiple detection must be confirmed by the service providers and be located in the appropriate range. Let $C$ be the maximum cost that user must pay for spectrum analysis and $c_{\kappa}-$ the cost of single mobile user at $\mathrm{k} \in K(\mathrm{j})$. It can be described in the following way [5]:

$$
\sum_{j=1}^{M} \sum_{k \in K(j)} c_{k} \sum_{i=1}^{N(j)} x_{k i} \leq C .
$$

The most acceptable users' division for the multiple detection can be described by the formula [6]:

$$
\max \sum_{j=1}^{M} \sum_{i=1}^{N(j)} \omega_{j}^{i} f(i, j),
$$

providing that

$$
\begin{gathered}
f(i, j) \geq H \text { i }[1, N(j)], \mathrm{j} \in[1, M], e_{k} \geq T h, \mathrm{k} \in K . \\
\sum_{k \in K(j)} \sum_{i=1}^{N(j)} x_{k i} \leq n(j), \\
\sum_{j=1}^{M} \sum_{k \in K(j)} c_{k} \sum_{i=1}^{N(j)} x_{k i} \leq C \\
\sum_{j=1}^{M} \sum_{i=1}^{N(j)} \omega_{j}^{i}=1 .
\end{gathered}
$$

In the figure 1, the example of the users' division for the multiple detection is shown. In the network, there are two locations and three channels. Each location is divided into three subzones. In the different subzones, the mobile users can receive different measuring results in the same channel. Some users cannot commit the spectrum analysis because they have the local constraints, high cost of request, or insufficient residual energy. The rest of the users will analyze the channels according to the expression 7.

The multiple detection task is hard to implement because it is NP-hard class task. The reason is that the multiple detection problem is as difficult as the maximum coverage area task [15]. Let $d$ - the number of $l$ array of order $S=\left\{S_{1}, S_{2}, \ldots, S_{l}\right\}, S^{\prime}$ - the maximum of the $d$ number:

$$
\max \left|\cup_{S_{i} \in S^{\prime}} S_{i}\right|
$$

where $S^{\prime} \subseteq S,\left|S^{\prime}\right| \leq d$.

In general, such task is described in the following way. Each mobile user having enough energy to carrying out the spectrum analysis sets the local threshold to 0 value. It means that the local constraint was fulfilled, detection cost lies within the permissible limits. It is supposed there are $K$ mobile users and $M$ locations. In every location it is existed $\mathrm{N}$ detected channels.



Detected channel 3

Not detected channel

Fig. 1. The example of the multiple detection architecture

Each mobile user is in range $i \in\{1,2, \ldots, K\}$. Let non-negative weight $\omega_{\mathrm{j}}^{\mathrm{i}}$ will be constant. Then (7) can be represented in the form:

$$
\max \sum_{j=1}^{M} \sum_{i=1}^{N(j)} f(i, j) .
$$

The equation (9) provides the choice of $d$ array for the sum maximization $f(i, j)$. In comparison with $(8)$, the task complexity level is at least the same as in the maximum coverage area task.

Since the multiple detection problem belongs to the task of HP-hard class, it was proposed the algorithm based on the particle swarm optimization with using the neural network. In the PSO algorithm, [15] each particle has its own search speed. The particle can change its value according to the neighbor particles parameters. Let $V_{i d}$ is the particle speed $X_{i d}$. Then the particle movement will be described in the following way:

$$
\begin{gathered}
V_{i d}^{t+1}=\omega V_{i d}^{t}+c_{1} r_{1}\left(P_{i d}-X_{i d}^{t}\right)+c_{2} r_{2}\left(P_{g d}-X_{i d}^{t}\right), \\
X_{i d}^{t+1}=V_{i d}^{t+1}+X_{i d}^{t} .
\end{gathered}
$$

where $\omega$ - the iteration weight,

$\mathrm{P}_{\text {id }}$ - the best one particle location,

$\mathrm{P}_{\mathrm{gd}}$ - the best one particle global,

$r_{1}$ and $r_{2}-$ the arbitrary numbers in range $[0 ; 1]$,

$\mathrm{c}_{1}$ and $\mathrm{c}_{2}-$ the learning factor.

The iteration weight $\omega$ allows the algorithm to improve its productivity. The formulas (10) and (11) allow calculating the speed and location of the particle.

According to the PSO algorithm, the location of each particle is the separate element of the multiple detection task. Let suppose that $N(j)$ channels in the 
locations $j \in[1, M]$ and the number of the detected channels will be $\sum_{j=1}^{M} N(j)$. Let $K$ denotes all mobile users. Then each particle is defined as $K \times \sum_{j=1}^{M} N(j) X$ matrix, where $\mathrm{X}[\mathrm{a}][\mathrm{b}]=1$ that defines the $a$ user of the $b$ detected channel and $\mathrm{X}[\mathrm{a}][\mathrm{b}]=0$ that defines the $a$ user of the $b$ not detected channel. It was proposed the algorithm based on the PSO with using the convolutional neural network (PSO-NN). The $q$ particles are initialized randomly and it is installed the particle with the highest objective function according to the formula (7) that is using according to the algorithm PSO. The fig. 2 shows the generalized algorithm PSO-NN.

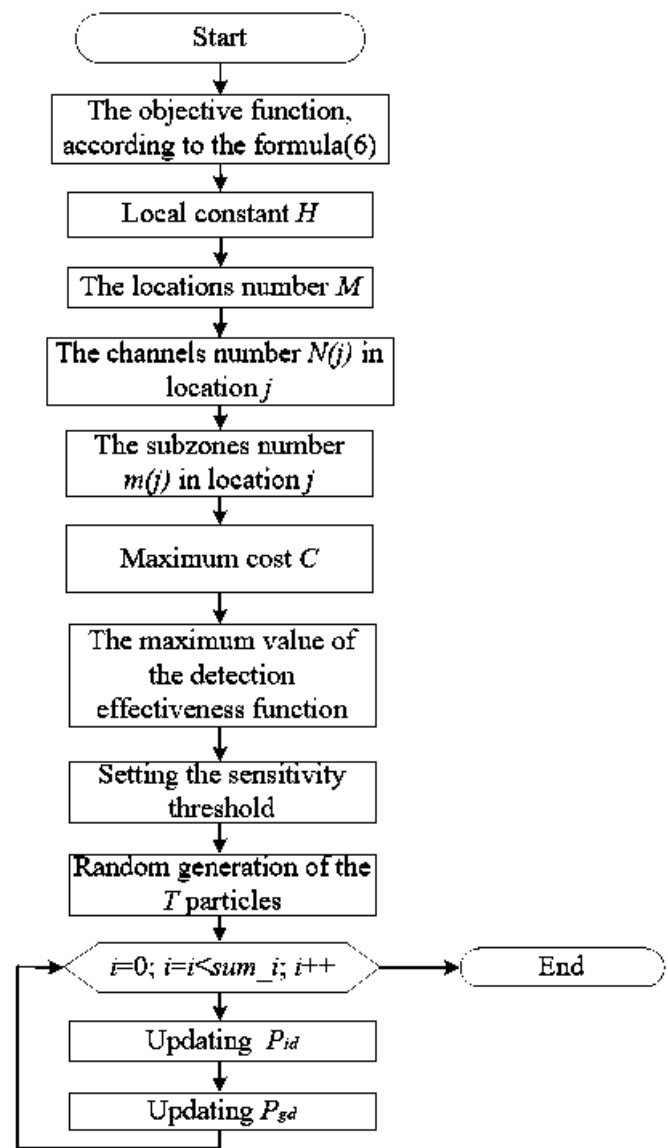

Fig. 2. The generalized algorithm PSO-NN

After each cycle of users' multiple detection, the analyzing energy of the user is decreased. Mobile user must detect that its remaining energy match the energy threshold. If the energy of the user that analyzes spectrum is higher than the threshold value, mobile user can analyze the spectrum again. For each particle of the swarm in case if the user's energy is not enough for the spectrum analysis, the recording of the vector of a given particle into a zero value of the corresponding matrix is carried out. Based on the current matrix the particle, effectiveness function can be found according to (1). After calculating the effectiveness function of all particles, one can receive a better particle location $P_{i d}$ and global location $P_{g d}$. The higher the effectiveness function value is, the better is the position of corresponding particle. Depending on the location $P_{i d}$ and $P_{g d}$, we will unite the matrices for the multiple detection optimization.
Let $T_{1}-$ the current matrix of the particle, $T_{2}$ and $T_{3}$ denote better and global matrices respectively. The united matrix can be described by the combination $T_{1}, T_{2}$ and $T_{3}$.

If several users in the united matrix detect the channel, only one user with higher residual energy will reserve the channel. After matrix uniting, only one element is bound to the column vector of this matrix. If the user's $T_{1}, T_{2}$ and $T_{3}$ are different, several column vectors of this matrix can exist. Considering the global properties of the PSO, we optimize the column vectors of the matrix determined by the parameters (10). If a user detects different channels in these three matrices, he will choose the channel in $T_{l}$ based on $\omega /\left(\omega+c_{1}+c_{2}\right)$, in $T_{2}$, based on $c_{1} /\left(\omega+c_{1}+c_{2}\right)$, and in $T_{3}$, based on $c_{2} /\left(\omega+c_{1}+c_{2}\right)$. It means that after merger only one particle is tied to the column vector in the united matrix. The search place and convergence speed of these particles can be adjusted setting the value $\omega, c_{1}$ and $c_{2}$. The algorithm of detection improvement is represented in the fig. 3 .



Fig. 3. The multiple detection improvement algorithm

Complexity of the proposed algorithm PSO-NN is calculated in the following way.

Proposed algorithm PSO-NN is evaluated by the way of modeling and compared to the algorithm in [14]. There are locations where the spectrum analysis with the same radiuses can be done. Each location is divided into three subzones. The number of channels is $5(N=5)$. The local threshold $H=0.57$. Non-negative weights are the same for each channel and each location. Mobile users are generated in the random locations.

In the figure 4 , the multiple detection effectiveness with a combined work of 50 mobile users from 15 to 40 
locations is shown. The cost coefficient $c_{\kappa}$ was chosen in the range $\{1,2, \ldots, 50\}$. The maximum cost $a \sum_{k=1}^{50} c_{k}$ where $a$ lies in the range from 0,6 to 0,8 . Normalized energy threshold $0,2 \leq T_{h} \leq 0,5$. The multiple detection effectiveness is calculated with (1). This function reflects the detection effect and its value lies in the range from 0 to 1. The value is closer to 1 , the detection function will be better. Compared to the developed method with realizations [13] and [14], one can notice that the algorithm that implements proposed method showed higher detection effect. As the number of locations increases, the detection effectiveness decreases. It happens because greater number of locations leads to the emergence of more quantity of the subzones and fixed number of the users cannot detect all subzones. In $T_{h}=0,2$ and $a=0,8$, the detection effectiveness function showed the highest values.

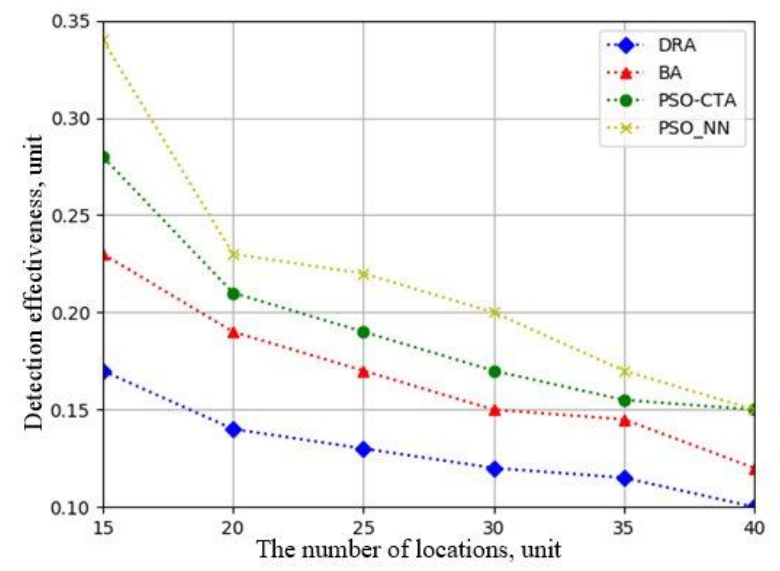

Fig. 4. The multiple detection effectiveness function for 50 mobile users

\section{Conclusions}

During the research, the multiple detection architecture was developed. It differs from the known architectures since each location is divided into the subzones. As a result, a mobile user can receive different measuring results in the same channel in different subzones. Such a division can be used for more flexible data use. Developed generalized algorithm PSO-NN is different since it is correctly configured for the real conditions inherent in the architecture of the cognitive systems. This algorithm uses particle swarm optimization controlled by the convolutional neural network. Therefore, strict access to spectrum analysis based on mobile users' energy component is provided. Due to the use of the micro particle architecture and convolutional neural networks, detection effectiveness function and global particle location are detected in a more accurate way. Further implementation of the multiple detection algorithm is different from the known since only one user is assigned to a specific channel after uniting the detected channel users' matrices. Additionally, such implementation assumes more realistic search area and speed of the users' detection with found channels. Modeling PSO-NN as the multiple detection effectiveness algorithm for 50 mobile users has several convolutional layers generalized with each other. Such architecture can be a confirmation that the neural network chosen satisfies the tasks largely. The modeling result showed that the detection effectiveness using the algorithm PSO-NN increased by $10 \%$ in 20 locations, by $20 \%$ in 25 locations, by $20 \%$ in 30 locations, by $20 \%$ in 35 locations, while the results did not change in 40 locations.

\section{REFERENCES}

1. Mitola III, J. and Maguire Jr., G.Q. (1999), "Cognitive radio: making software radios more personal", IEEE Personal Communications, Vol. 6, no. 4, pp. 13-18.

2. Guo, B. Wang, Z., Yu Z. et al. (2015), "Mobile crowd sensing and computing: the review of an emerging human-powered sensing paradigm”, ACM Computing Surveys, Vol. 48, No. 1, Article 7.

3. Saleem, Y. and Rehmani, M.H. (2015), "Primary radio user activity models for cognitive radio networks: a survey", Journal of Network and Computer Applications, Vol. 43, pp. 1-16.

4. Arslan, H. (2009), "A survey of spectrum sensing algorithms for cognitive radio applications", IEEE Communications Surveys \& Tutorials, Vol. 11, No. 1, pp. 116-130.

5. Zeng, F., Tian, Z. and Li, C. (2010), "Distributed compressive wideband spectrum sensing in cooperative multi-hop cognitive networks", Proceedings of the 2010 IEEE International Conference on Communications, ICC 2010.

6. Feng, J., Lu, G., Wang, H. and Wang, X. (2016), "Supporting secure spectrum sensing data transmission against SSDH attack in cognitive radio ad hoc networks", Journal of Network and Computer Applications, Vol. 72, pp. 140-149.

7. Zhang, R., Zhang, J., Zhang, Y. and Zhang, C. (2013), "Secure crowdsourcing-based cooperative pectrum sensing," Proceedings of the 32nd IEEE Conference on Computer Communications, IEEE INFOCOM 2013, pp. 2526-2534.

8. Lu, Y., Wang, D. and Fattouche, M. (2016), "Cooperative spectrum-sensing algorithm in cognitive radio by simultaneous sensing and BER measurements", Eurasip Journal on Wireless Communications and Networking, Vol. 2016, No. 1, Article 136.

9. Liu, C.-H., Azarfar, A., Frigon, J.-F., Sansò, B. and Cabric, D. (2015), "Robust cooperative spectrum sensing scheduling optimization in multi-channel dynamic spectrum access networks", IEEE Trans. on Mobile Computing, Vol. 15, No. 8, pp. $2094-2108$.

10. Zhu, J., Jiang, D., Ba, S. and Zhang, Y. (2017), "A game-theoretic power control mechanism based on hidden Markov model in cognitive wireless sensor network with imperfect information," Neurocomputing, Vol. 220, pp. 76-83.

11. Arora, P., Xia,N. and Zheng, R. (2011), "A Gibbs sampler approach for optimal distributed monitoring of multi-channel wireless networks", Proceedings of the 54th Annual IEEE Global Telecommunications Conference: "Energizing Global Communications", GLOBECOM 2011.

12. Shin, D.-H., Bagchi, S. and Wang, C.-C. (2012), "Distributed online channel assignment toward optimal monitoring in multichannel wireless networks", Proc. of the IEEE Conf. on Computer Communications, IEEE INFOCOM 2012, pp. 2626-2630.

13. Shin, D.-H. and Bagchi, S. (2013), "An optimization framework for monitoring multi-channel multi-radio wireless mesh networks," Ad Hoc Networks, Vol. 11, No. 3, pp. 926-943.

14. Shin, D.-H., He, S. and Zhang, J. (2015), "Joint sensing task and subband allocation for large-scale spectrum profiling", Proc. of the 34th IEEE Annual Conference on Computer Communications and Networks, IEEE INFOCOM 2015, pp. 433-441. 
15. Eberhart, R.C. and Kennedy, J. (1995), “A new optimizer using particle swarm theory”, Proceedings of the 6th International Symposium on Micro Machine and Human Science (MHS '95), pp. 39-43, Nagoya, Japan, 1995.

Received (Надійшла) 16.03.2018

Accepted for publication (Прийнята до друку) 23.05.2018

\section{Метод множинного виявлення мобільних користувачів на основі оптимізації рою частинок в когнітивній радіомережі}

\section{Я. Я. Обіход}

Об’єктом вивчення в статті є процеси множинного виявлення мобільних користувачів на основі оптимізації рою частинок в когнітивній радіосистемі. Мета досліджень лежить в області алгоритмів виявлення мобільних користувачів когнітивної радіосистеми, в розробці узагальненого алгоритму PSO-NN і поліпшенні методу множинного виявлення шляхом використання методу рою частинок і згорткової нейронної мережі, а також його реалізації. Завдання: розробка архітектури множинного виявлення; розробка узагальненого алгоритму PSO-NN; виконання подальшої реалізації алгоритму множинного виявлення; реалізація моделювання PSO-NN, як алгоритму ефективності множинного виявлення для 50 мобільних користувачів. Використовуваними методами є: математичні моделі, побудовані за принципом організації та функціонування біологічних нейронних мереж, математичні моделі навчання, методи теорії алгоритмів NP-hard. Отримані наступні результати. В ході досліджень було розроблено архітектуру множинного виявлення, яка відрізняється від відомих тим, що кожна локація розділена на підзони. В результаті, мобільні користувачі можуть в різних підзонах отримувати різні результати вимірювань в одному і тому ж каналі. Такий розподіл може використовуватися для більш гнучкого використання даних. Розроблений узагальнений алгоритм PSO-NN відрізняється від відомих тим, що він більш коректно налаштовується на реальні умови, властиві архітектурі когнітивних систем. Цей алгоритм використовує оптимізацію рою частинок під керуванням згорткової нейронної мережі. Завдяки цьому забезпечується суворий доступ до аналізу спектру на основі енергетичної складової мобільних користувачів. За рахунок використання мікрочасткової архітектури та згорткових нейронних шарів, функція ефективності виявлення і глобальне розташування частинок визначаються більш точно. Подальша реалізація алгоритму множинного виявлення відрізняється від відомих тим, що після об'єднання матриць користувачів виявлених каналів, тільки один користувач закріплюється за певним каналом. Також, така реалізація передбачає більш реалістичний простір пошуку і швидкість виявлення користувачів зі знайденими каналами. Моделювання PSO-NN, як алгоритм ефективності множинного виявлення для 50 мобільних користувачів, має кілька згорткових шарів, які узагальнено один з одним. Така архітектура може бути підтвердженням того, що обрана практичним шляхом нейронна мережа більшою мірою задовольняє поставленим завданням. Результати моделювання показали, що при 20 локаціях, ефективність виявлення з використанням алгоритму PSO-NN зросла на 10 \%, при 25 локаціях - на 20\%, при 30 локаціях - на 20\%, при 35 - на 20\%, при 40 не змінилась.

Ключов і слов а: когнітивне радіо; алгоритм рою частинок; згорткова нейронна мережа; радіочастотний ресурс; задача класу NP-hard.

\section{Метод множественного определения мобильных пользователей на основе оптимизации роя частиц в когнитивной радиосети}

\section{Я. Я. Обиход}

Объектом изучения в статье являются процессы множественного обнаружения мобильных пользователей на основе оптимизации роя частиц в когнитивной радиосети. Цель исследований лежит в области алгоритмов обнаружения мобильных пользователей когнитивной радиосистемы, в разработке обобщенного алгоритма PSO-NN и улучшении метода множественного обнаружения путем использования метода роя частиц и сверточной нейронной сети, а также его реализации. Задача: разработка архитектуры множественного обнаружения; разработка обобщенного алгоритма PSO-NN, дальнейшая реализация алгоритма множественного обнаружения; реализация моделирования PSO$\mathrm{NN}$, как алгоритма эффективности множественного обнаружения для 50 мобильных пользователей. Используемыми методами являются: математические модели, построенные по принципу организации и функционирования биологических нейронных сетей, математические модели обучения, методы теории алгоритмов NP-hard. Получены следующие результаты. В ходе исследований была разработана архитектура множественного обнаружения, которая отличается от известных тем, что каждая локация разделена на подзоны. В результате, мобильные пользователи могут в различных подзонах получать различные результаты измерений в одном и том же канале. Такое распределение может использоваться для более гибкого использования данных. Разработан обобщенный алгоритм PSO-NN , который отличается от известных тем, что он более корректно настраивается на реальные условия, присущие архитектуре когнитивных систем. Этот алгоритм использует оптимизацию роя частиц под управлением сверточной нейронной сети. Благодаря этому, обеспечивается строгий доступ к анализу спектра на основе энергетической составляющей мобильных пользователей. За счет использования микрочастичной архитектуры и сверточных нейронных слоев, функция эффективности определения и глобальное расположения частиц определяются более точно. Дальнейшая реализация алгоритма множественного определения отличается от известных тем, что после объединения матриц пользователей выявленных каналов, только один пользователь закрепляется за определенным каналом. Также, такая реализация предполагает более реалистичное пространство поиска и скорость обнаружения пользователей с найденными каналами. Моделирование PSO-NN, как алгоритм эффективности множественного обнаружения для 50 мобильных пользователей, имеет несколько сверточных слоев, обобщенных друг с другом. Такая архитектура может быть подтверждением того, что выбранная практическим путем нейронная сеть в большей степени удовлетворяет поставленным задачам. Результаты моделирования показали, что при 20 локациях, эффективность обнаружения с использованием алгоритма PSO-NN выросла на 10\%, при 25 локациях - на 20\%, при 30 локациях - на 20\%, при 35 - на 20\%, при 40 не изменилась.

Ключевые слова: когнитивное радио; алгоритм роя частиц; сверточная нейронная сеть; радиочастотный ресурс; задача класса NP-hard. 